\title{
Brølet i kommentarsporet: Journalisters formidling af den offentlige opinion på politiken.dk
}

\author{
AF RASMUS RøNLEV
}

\section{Resumé}

Artiklen præsenterer et casestudie af et forløb i vinteren 2012 hvor en ung studerendes indlæg om hendes trange studenter$ø$ konomi skabte voldsom debat på politiken.dk. På baggrund af en retorisk analyse påvises det hvordan den offentlige opinion der manifesterede sig i netavisens kommentarspor, blev påfaldende forenklet i den danske medieomtale af debatten: Det flerstemmige kor af argumenter i kommentarsporet som analysen afdækker, blev i danske medier reduceret til en enstemmig kritik af den studerende og hendes indlæg. Studiet viser hvordan journalisters rolle som privilegerede fortolkere og formidlere af den offentlige opinion undertiden ikke blot fastholdes på nettet, men forstærkes.

\section{Introduktion}

I takt med udbredelsen af digitale netværksmedier har iagttagere sået tvivl om journalisters rolle som bindeled mellem - eller gatekeepers for - politisk debatterende kommunikation mellem borgere og magthavere; tilsyneladende kan parterne jo nu kommunikere direkte med hinanden, for eksempel på de sociale medier (Bro og Wallberg 2015: 99). Flere retorikere har i lyset af medieudviklingen fremsat den håbefulde hypotese at debatterende borgeres hverdagsretorik på nettet i stigende grad vil udfordre den autoritet som retorikken fra traditionelt privilege- 
rede kommunikatører som journalister indtil nu har nydt (Hauser, 2007: 338; Howard, 2010: 256--257; Ingraham, 2013: 17-18). Eksempelvis Gerard A. Hauser har fremhævet at nettet gør det muligt for borgere hurtigt og effektivt at påvirke den offentlige opinion og i sidste ende de politiske beslutningstagere, ikke blot uden journalisters indblanding, men undertiden som udtryk for en direkte destabilisering af journalisters privilegerede position som moderatorer for den offentlige meningsdannelse (Hauser, 2007: 338). Også nyhedsmediernes egne digitale platforme kan principielt understøtte en sådan mere direkte kommunikationsstrøm fra borgere til magthavere. Ikke alene kan borgere her dele deres erfaringer og holdninger i debatindlæg og lignende; i kommentarspor kan andre gøre det samme, og ved at læse, dele og kommentere kan borgere være med til at skabe opmærksomhed om en sag og på den måde bidrage til at få magthaverne i tale. Med netaviser som understøttende mellemled kan borgere ideelt set sætte en politisk dagsorden og gøre deres indflydelse gældende.

I denne artikel argumenterer jeg imidlertid for at digitale netværksmedier som netaviser og den kommunikation mellem borgere og magthavere de muliggør, ikke har overflødiggjort journalister som fortolkere og formidlere af den offentlige opinion, tværtimod. Journalisters formidling af debatter på netaviser kan stadig have afgørende betydning for de debatterende borgeres retoriske agency. Agency skal her forstås som det dialektiske samspil mellem borgernes individuelt betingede evner og strukturelt betingede muligheder for at handle retorisk og opnå indflydelse (Gunn og Cloud, 2010; Hoff-Clausen, Isager og Villadsen, 2005; Isager, 2009)..$^{1}$ I mine analyser vil jeg vise at idet journalister omtaler debatter på netaviser og fortolker og formidler hvad debatterne handler om, og hvad debattørerne mener, er journalisterne i høj grad med til at bestemme borgernes muligheder for at opnå opmærksomhed og øve indflydelse på den politiske meningsdannelse i den bredere offentlighed.

Tidligere studier har vist at også journalister mener at det har stort demokratisk potentiale at åbne for borgeres kommentarer på netaviser: På den måde kan nyhedsmedierne styrke deres idealfunktion som kanaler for offentlig debat og være med til at demokratisere den offentlige meningsdannelse ved at lade 
flere og nye stemmer komme til orde (Braun og Gillespie, 2011: 386; Robinson, 2010: 132; Singer, 2010: 134 og 138; Singer og Ashman, 2009: 13 og 18). Denne opfattelse er så udbredt blandt journalister at journalistikforskeren David Domingo ligefrem har kaldt den en stærk, socialt konstrueret myte (Domingo, 2008: 682-683). Myten har imidlertid vist sig svær at realisere i praksis. Ifølge journalister skyldes det at borgernes kommentarer generelt er af lav kvalitet (Bergström og Wadbring, 2015: 143; Chung, 2007: 56; Diakopoulos og Naaman, 2011: 136; Singer, 2010: 133; Winsvold, 2009: 47 og 51) og fyldt med personangreb, ikke kun borgerne imellem, men også på journalisternes kilder (Braun og Gillespie, 2011: 388; Canter, 2013: 612; Diakopoulos og Naaman, 2011: 136; Loke, 2012: 239). Flere journalister mener derfor at de stadig bør indtage rollen som gatekeepere, også for debatter på netaviser (Hermida og Thurman, 2008: 350-351 og 353-354; Singer, 2010: 138). Mængden af kommentarer betyder dog at det ofte kan være en særdeles ressourcekrævende opgave at moderere debatterne og finde og fremhæve de momenter af kvalitet der måtte være i dem (Braun og Gillespie, 2011: 386-389; Chung, 2007: 56; Diakopoulos og Naaman, 2011: 141; Robinson, 2010: 135; Thurman, 2008: 147 og 152; Winsvold, 2009: 47-48 og 52). Disse negative praksiserfaringer til trods giver journalister ikke desto mindre også udtryk for at kommentarspor på netaviser kan være en journalistisk ressource, for eksempel som kilde til nye historier og vinkler, ekspertviden og kritik der kan føre til faglig disciplin og udvikling (Diakopoulos og Naaman, 2011: 140; Graham og Wright, 2015: 320 og 328-332; Hermida og Thurman, 2008: 349 og 352; Loke, 2012: 238-239; Singer, 2010: 135).

Alle de nævnte studier af journalisters erfaring med og opfattelse af kommentarspor på netaviser baserer sig på interviews, surveys og observationer. Enkelte af studierne supplerer dette med indholdsanalyser af kommentarspor og sammenholder journalisters opfattelse af kommentarsporene med kommentarsporenes faktiske indhold (Canter, 2013: 606; Graham og Wright, 2015: 321-323). I ingen af studierne undersøges journalisters tekster, for eksempel omtaler af debatter på netaviser, og hvordan de tekster spiller sammen med borgeres tekster, for eksempel debatindlæg og kommentarer, i længere debatforløb på tværs af medietyper og kommunikationsformer. En grundantagelse i 
denne artikel er imidlertid at offentlig meningsdannelse er en dynamisk proces der manifesterer sig i offentlig retorik, hvorfor man må vende blikket mod netop tekster og deres intertekstuelle samspil hvis man vil undersøge journalisters betydning for den opmærksomhed og indflydelse borgere kan få i offentligheden (jf. Hauser, 1999: 84-85 og 275-277). Derfor tager jeg udgangspunkt i dette samspil mellem borgeres og journalisters tekster og præsenterer et casestudie af debat blandt borgere på en netavis og journalisters omtale af samme. Det centrale spørgsmål er hvordan journalisterne tilskriver de debatterende borgere retorisk agency.

Studiet tager afsæt i et debatforløb i vinteren 2012 hvor den indtil da ukendte studerende Sofie V. Jensen (SVJ) skabte voldsom debat i danske medier. D. 7. januar fik hun publiceret et debatindlæg både i Politiken ${ }^{2}$ og på politiken.dk ${ }^{3}$ der handlede om hendes trange studenterøkonomi. På få dage fik indlægget små 2.000 kommentarer på politiken.dk, og hurtigt spredte debatten sig til andre nyhedsmedier, blogs og debatfora på nettet. Efterhånden som indlægget resulterede i rekordmange kommentarer på Politikens netavis ${ }^{4}$ og skabte debat på tværs af danske webmedier, begyndte flere journalister, politikere og andre meningsdannere at tage del i debatten. I ugen der fulgte, blev den megen opmærksomhed som indlægget fik på nettet, desuden vekslet til opmærksomhed i de traditionelle massemedier. SVJ endte på forsiden af både Ekstra Bladet ${ }^{5}$ og Kristeligt Dagblad ${ }^{6}$ og besøgte såvel Go'morgen Danmark på TV $2^{7}$ som Deadline på DR2 ${ }^{8}$. I den megen medieomtale indledte journalisterne typisk med at slå fast hvor mange der havde læst og kommenteret den studerendes indlæg på politiken.dk. Samtidig konstaterede de at flertallet var negativt, ja, ligefrem fjendtligt stemt over for hende. Den dominerende historie i danske medier var at SVJ måske nok fik sat en dagsorden med sit indlæg, men også at hun blev sat godt og grundigt på plads af sine medborgere. Ikke desto mindre lykkedes det hende at råbe flere politiske magthavere op, både medlemmer af Folketinget ${ }^{9}$ og ikke mindst uddannelsesminister Morten Østergaard der medgav "at danske studerende (...) ikke [levede] i sus og dus". ${ }^{10}$

Casen er interessant fordi den umiddelbart fremstår som et prototypisk eksempel på hvordan webmedier og herunder 
netaviser ikke kun kan understøtte politisk debatterende kommunikation fra magthavere til borgere, men også fra borgere til magthavere. Politikens opinionsredaktør Per Michael Jespersen mente at forløbet var et eksempel på en "nedefra og op-debat", ${ }_{11}$ og avisens lederskribent Kristian Madsen så det som "et stærkt tegn på den helt særlige danske debatkultur, hvor 'almindelige' mennesker også kan komme til i avisernes spalter". ${ }^{12}$ Madsen mente imidlertid også at forløbet illustrerede at der var forskel på at blive hørt og så at blive forstået: "Det er et ubetinget gode ved den danske offentlige debat, at selv en ung studerende kan sætte en dagsorden. Nu mangler vi blot, at de professionelle debattører også forsøger at forstå, hvad de [ikke-professionelle debattører] skriver." Adskillige af de "professionelle debattører" Madsen kritiserede, var journalister. Som hans kritik antyder, er casen også interessant fordi den illustrerer at debat blandt borgere på nettet måske nok kan sætte den offentlige dagsorden, men at journalister fortsat spiller en rolle som fortolkere og formidlere af hvad den dagsorden så er, og hvilke argumenter der er fremherskende blandt de debatterende borgere.

Artiklens analyse falder i tre trin: Jeg analyserer SVJ's debatindlæg, de små 2.000 kommentarer det afstedkom på politiken. $\mathrm{dk}$, og den omtale som såvel indlægget som kommentarerne fik i danske medier. Ved at sammenholde mine analyser vurderer jeg hvor retvisende de journalister der skrev om debatten, udlagde de spørgsmål og synspunkter der kom til udtryk i indlægget og kommentarerne på Politikens netavis. På den baggrund diskuterer jeg journalisters rolle som retorisk privilegerede fortolkere og formidlere af den offentlige opinion på nettet. Inden jeg skrider til analysen, vil jeg dog først uddybe dens teoretiske afsæt og metodiske greb.

\section{Journalisters retoriske privilegier i den offentlige meningsdannelse}

I en artikel om politisk kommunikation i medierede massedemokratier har Jürgen Habermas peget på at samfundet kan anskues som et kommunikativt hierarki (Habermas, 2006: 419; se også Rønlev, 2014: 43-46). Lagdelingen i dette hierarki beror 
ifølge Habermas på en ulige distribution af magt, det være sig politisk magt, social magt, økonomisk magt eller magt over medierne (Habermas, 2006: 418-419). Ud fra et retorisk perspektiv betyder dette at nogle kommunikatører nyder retoriske privilegier i den offentlige sfære som andre kommunikatører ikke gør. Eksempelvis har journalister i kraft af deres tilhørsforhold til pressen som samfundsinstitution (og den magt over medierne det indebærer) generelt nemmere ved at få taletid og ørenlyd i offentligheden end de fleste borgere. Hvad Habermas implicit peger på, er altså at der eksisterer institutionaliserede forskelle $i$ retorisk agency i den offentlige sfære (se også Rønlev, 2014: 47-49). Ikke i den forstand at journalisters retoriske handleevne nødvendigvis er bedre end de fleste borgeres, men i den forstand at deres retoriske handlemulighed er det.

Traditionelt har journalister derfor haft privilegeret mulighed for at øve indflydelse på den offentlige opinion. Retorikeren Gerard A. Hauser har argumenteret for at den offentlige opinion træder frem i samfundets fortsatte multilog, med hvilket han mener et netværk af samtaler blandt engagerede borgere, ikke kun i den politiske offentlige sfære, men i alle samfundets sfærer (Hauser, 1999: 65, 74 og 93-108). Her er praktisk argumentation - eller retorik om man vil - afgørende for at en offentlighed kan nå en fælles forståelse og vurdering af et samfundsmæssigt anliggende og på den baggrund give udtryk for en egentlig offentlig opinion (Hauser, 1999: 65, 74 og 93-108). Vil man vide hvad offentligheder mener, og hvordan de kommer til at mene det, må man derfor studere offentlig retorik, vel at mærke både den formelle retorik fra privilegerede debattører som eksempelvis journalister og den mere uformelle hverdagsretorik blandt mindre privilegerede debattører som de fleste almindelige borgere (Hauser, 1999: 85).

På trods af at den offentlige meningsdannelse ifølge Hauser ikke begrænser sig til en lille elites diskussioner i institutionelle fora som pressen og parlamentet, anerkender han ikke desto mindre at journalister indtager en retorisk privilegeret position i den multilog han beskriver, netop på grund af deres adgang til medierne (Hauser, 1999: 275 og 277). Som debattører har journalister ikke alene nemmere ved at få udbredt deres synspunkter; i kraft af deres profession som nyhedsformidlere (Bro, 2009: 382) 
har de særlig adgang til de politiske magthavere og dermed større indblik i baggrunden for politiske forslag og bevæggrundene hos forslagsstillerne. Derfor nyder kommentatorer og redaktører en naturlig opmærksomhed i offentligheden som de fleste borgere ikke gør. Også som multilogens moderatorer (se også Hansen, 2015: 104-105) nyder journalister særlige privilegier. I kraft af deres adgang til nyhedsmedierne som platforme for offentlig debat (Bro, 2009: 382) har de ikke alene indflydelse på hvad der sættes til debat, og hvilke indlæg der bringes, men også hvordan debatten og herunder den offentlige opinion bør fortolkes.

Disse traditionelle privilegier har medieudviklingen som sagt sat til debat. Som medieforskeren Klaus Bruhn Jensen har påpeget, har udbredelsen af digitale netværksmedier fundamentalt forandret samfundets kommunikationsstrømme, altså strømme af information på tværs af forskellige medietyper og kommunikationsformer (Jensen, 2012: 186-189). Hvor disse tidligere har været domineret af én til én-kommunikation ansigt til ansigt og én til mange-kommunikation i traditionelle massemedier, er der ifølge Jensen i dag føjet et tredje trin til disse to, nemlig mange til mange-kommunikation i digitale netværksmedier (Jensen, 2009: 335-36, 2010: 64; Jensen og Helles, 2011: 528-529; Jensen, 2012: 188). Udviklingen er, som jeg var inde på indledningsvis, blevet set som udtryk for en demokratisering af den offentlige meningsdannelse: Via de digitale netværksmedier skulle flere borgere kunne gøre deres indflydelse gældende som offentlige debattører (Hindman, 2009: 6). Og den mere direkte kommunikation mellem borgere og magthavere som netværksmedierne tilsyneladende muliggør, skulle desuden overflødiggøre journalister som moderatorer (Bro og Wallberg, 2015: 99).

Såvel politologiske som retoriske studier antyder dog at journalisters retoriske privilegier i den offentlige debat består, også i digitale netværksmedier. I et ofte citeret studie har politologen Matthew Hindman eksempelvis vist hvordan journalister med tilknytning til de etablerede nyhedsmedier løber med langt størstedelen af opmærksomheden i den politiske blogosfære i USA (Hindman, 2009: 116-117 og 122). Som debattører har journalister altså også online nemmere ved at komme til orde og blive hørt. Tilsvarende har retorikeren Christine Isager i et studie af Berlingske Tidendes journalistiske projekt Forbrydelsen fra 2008 
vist hvordan journalister også på nettet indtager en privilegeret rolle som moderatorer for offentlig meningsdannelse (Isager, 2009: 287). Det er netop journalisters forvaltning af denne rolle som denne artikels analyser kaster lys over.

Casestudiet der følger, er en retorisk kritik (se Isager, 2015: 6; Lund og Roer, 2014; Villadsen, 2009) der baserer sig på nærlæsninger af tekster og de intertekstuelle reaktioner de afstedkommer (se Ceccarelli, 2001; Hauser, 1999: 275-277). Jeg undersøger det forløb som SVJ's debatindlæg igangsatte, ved i tre trin at analysere indlægget, så dets kommentarspor på politiken.dk og til sidst den omtale begge fik i danske medier. I denne trinvise analyse fokuserer jeg først på hvilke argumenter SVJ fremsatte i sit indlæg, siden hvilke (mod)argumenter hendes indlæg blev mødt med i kommentarsporet, og endelig hvilke af argumenterne i henholdsvis indlægget og kommentarsporet der blev videreformidlet af journalister i medieomtalen. I analyserne af kommentarsporet og medieomtalen supplerer jeg mine kvalitative analyser af hvilke argumenter der var at finde i analyseteksterne, med kvantitative optællinger af hvor udbredte de argumenter var. På den måde kortlægger jeg hvilke argumenter der dominerede $\mathrm{i}$ forskellige trin af kommunikationsstrømmen, og påviser i sidste ende en påfaldende diskrepans mellem den offentlige opinion der manifesterede sig i kommentarsporet på Politikens netavis, og hvordan denne blev udlagt i danske medier.

\section{Fra én borger til mange: Hvad skrev Sofie V. Jensen?}

SVJ's debatindlæg blev offentliggjort på et tidspunkt hvor der var røre i folkestemningen med hensyn til hvad det ville sige at være fattig i Danmark, og hvordan ansvarsfordelingen mellem borger og stat i den forbindelse burde være. ${ }^{13}$ Det skyldtes ikke mindst debatten nogle måneder forinden om "Fattige Carina", en enlig mor på kontanthjælp som Özlem Cekic, MF for Socialistisk Folkeparti, i november 2011 brugte som et eksempel på en fattig dansker i en konfrontation med Joachim B. Olsen, MF for Liberal Alliance. ${ }^{14}$ Debatten om Carina kan dog ikke alene forklare at det så eftertrykkeligt lykkedes for SVJ at skabe opmærksomhed om sig selv og sin sag. En del af forklaringen på den megen virak skal 
også findes i det indlæg som den studerende sendte til Politikens debatredaktion.

Karakteristisk for debatindlægget var først og fremmest at det ikke havde ét klart formål. En teksts formål skal her forstås som dens "budskab, idé eller grundpåstand - altså det, man helt grundlæggende vil med teksten” (Pontoppidan, 2013: 21). I stedet indeholdt indlægget to formål og henvendte sig dermed også til to forskellige retoriske publikummer, altså beslutnings- og handledygtige personer i den pågældende kommunikationssituation ("mediators of change", jævnfør Bitzer, 1968: 7-8). At det således var uklart både hvad SVJ ville med sit indlæg, og hvem det var hun forsøgte at få i tale, kan være med til at forklare den store spredning i reaktioner som det vil vise sig at hendes indlæg afstedkom.

Det primære formål i SVJ's debatindlæg var at udtrykke frustration over at hendes omgivelser "ingen tolerance og forståelse" havde for at hun var fattig, hvorfor hun med egne ord følte sig "ekskluderet" og "ensom". Samtidig postulerede medierne ifølge hende at "man [kunne] leve i luksus på SU”, og at unge var "rige, fordrukne modedyr, der [tog] til dyre fester i weekenden og [drak] caffelatte i frokostpausen”. På den baggrund appellerede hun til "mere sammenhold og forståelse de studerende imellem" og efterlyste at omgivelserne tog højde for hendes situation når der for eksempel skulle holdes fest på studiet, fejres jul i familien eller skrives om studieliv i medierne. "Hvad blev der af sammenskudsgilde og medbragt alkohol fra Fakta?", spurgte hun retorisk. Dette formål fremstod som indlæggets vigtigste, ikke mindst fordi SVJ afslutningsvis slog fast at det var "okay" at hun ikke havde råd til en caffe latte, men at det "ikke [var] okay" at andre ikke tolererede eller forstod det. Det retoriske publikum for dette budskab var en relativt bred gruppe, nemlig SVJ's medstuderende, hendes familie og "det generelle samfund", som hun formulerede det.

Det sekundære formål i SVJ's indlæg var at udtrykke frustration over at hun var fattig, en påstand hun underbyggede med et eksempel på sit månedlige budget der viste at hun - uden studielån - havde et månedligt rådighedsbeløb på $329 \mathrm{kr}$. Hun var derfor "træt af at være (...) nødsaget til at plage [s]ine forældre om at betale transporten hjem i ferien" og "af ikke at have råd til p-piller og vitamintilskud”, men også af "at vågne med koldsved 
og hjertebanken", "være træt og uoplagt" og kort og godt "have en dårlig dag hver dag”. Det var uklart hvad SVJ præcis advokerede for i forlængelse af dette; men hun skrev blandt andet at hun var "træt af, at det [var] (...) en kliche at kæmpe for højere SU", og at hun følte sig "opgivende" når hun så "hvor lidt uddannelsessystemet [tog] hensyn til, at man [var] nødt til at tjene penge ved siden af studiet". Det retoriske publikum for dette andet, mindre udfoldede budskab var en noget mere snæver, men ikke mindre vagt defineret gruppe af andre studerende der som SVJ ønskede at SU- og uddannelsessystemet blev reformeret, og politikere der med politiske indgreb kunne få det til at ske.

Debatindlæggets tvetydighed med hensyn til formål og publikum blev yderligere underbygget af dets stilistik og syntaks. Det mest karakteristiske stilistiske træk var anaforen "Jeg er træt af at...”. Formuleringen faldt første gang midt i indlæggets anden periode og indledte herefter 18 af de første 24 perioder i indlægget (som indeholdt 34 perioder i alt). De ting der trættede SVJ, hobede sig op, og når hun på indholdssiden beskrev følelsen af at være overvældet, understøttedes dette af formen. Samtidig var alle de sætninger som anaforen indledte, sideordnede, hvorfor de ophobede elementer umiddelbart var ligestillede. Anaforen indledte således både perioder som knyttede sig til indlæggets primære formål, og perioder der knyttede sig til dets sekundære formål: SVJ var på én gang "træt af at føle [s]ig ekskluderet, oven i købet mellem [s]ine medstuderende" og "træt af at få at vide, at [hun] ikke [kunne] kalde [s]ig fattig". Som tilfældet er med anaforer generelt, var gentagelsesfiguren med til at understrege indlæggets agiterende karakter med patosfyldt emfase (jævnfør Albeck, 2000: 165); samtidig var de mange sideordnede perioder som anaforen indledte, med til at fastholde det dobbelte formål og adressatforhold.

\section{Fra mange borgere til mange: Hvad skrev debattørerne på politiken.dk?}

I analysens næste trin analyserer jeg de 1.971 kommentarer som SVJ's debatindlæg fik på politiken.dk. ${ }^{15}$ Når jeg citerer fra kommentarsporet, angiver jeg med et tal i parentes hvilken kom- 
mentar jeg citerer fra. Tallet 1 henviser til den første kommentar der blev publiceret på Politikens netavis, mens tallet 1.971 henviser til den sidste kommentar der blev publiceret på netavisen.

Jeg har brugt de ni kategorier i Tabel 1 til at karakterisere hvordan de mange kommentarer på politiken.dk relaterede til SVJ's debatindlæg. De ni kategorier er i tabellen eksemplificeret med citater fra kommentarsporet; disse eksempler supplerer jeg nedenfor med en uddybende karakteristik af de argumenter der gik igen i hver af de ni kategorier. Tilsammen tjener kategorierne og karakteristikken af dem til at give et overblik over den reaktion som SVJ og hendes indlæg blev mødt med i kommentarsporet på Politikens netavis.

Kategoriseringen der følger, beror for det første på emne: Kommenterede den enkelte debattør det primære formål i SVJ's indlæg, det sekundære formål eller noget andet? Med afsæt i analysen af debatindlægget har jeg kategoriseret kommentarerne ud fra om debattørerne forholdt sig til SVJ's argument om at fattigdom var et spørgsmål om eksklusion (det primære formål), hendes argument om at fattigdom var et spørgsmål om definition (det sekundære formål), eller noget andet.

For det andet beror kategoriseringen på holdning: Udtrykte den enkelte debattør enighed eller støtte, var han eller hun i tvivl eller neutral, eller udtrykte han eller hun uenighed eller kritik? Igen har jeg taget afsæt i analysen af SVJ's debatindlæg og kategoriseret kommentarerne ud fra hvordan debattørerne tog stilling til argumenterne i indlægget. 
Tabel 1. De ni kategorier som jeg har brugt til at kategorisere og optælle kommentarerne til Sofie V. Jensens debatindlæg på politiken.dk. Det er værd at bemærke at kategorierne ikke er anvendt gensidigt ekskluderende. Kategorierne er i tabellen eksemplificeret med citater fra kommentarsporet; her som i analysen i øvrigt gælder at alle sprogfejl også var i de oprindelige kommentarer.

\begin{tabular}{|c|c|c|c|}
\hline \multirow[b]{2}{*}{$\begin{array}{l}\text { Hvilken } \\
\text { holdning } \\
\text { udtrykte } \\
\text { den enkelte } \\
\text { debattør? }\end{array}$} & \multicolumn{3}{|c|}{ Hvilket emne kommenterede den enkelte debattør? } \\
\hline & Det primære formål & Det sekundære formål & Noget andet \\
\hline Enig/støtte & $\begin{array}{l}\text { “Jeg synes blot du } \\
\text { efterlyser mere solida- } \\
\text { ritet og forståelse for } \\
\text { når man ikke har råd } \\
\text { til at deltage i ting som } \\
\text { studerende og så efter- } \\
\text { lyser du sammenskud- } \\
\text { gilder og øl fra fakta } \\
\text { og jeg kunne ikke være } \\
\text { mere enig." (118) }\end{array}$ & $\begin{array}{l}\text { "Jeg forstår dig så } \\
\text { godt. SU'en rækker } \\
\text { bare ikke og folk skal } \\
\text { ikke komme og sige at } \\
\text { det er nok. (...) Ofte } \\
\text { koster bare en bog en } \\
\text { fjerdel af ens SU. Hvis } \\
\text { vi skal tage en uddan- } \\
\text { nelse så skal der kunne } \\
\text { leves af SU'en." (31) }\end{array}$ & $\begin{array}{l}\text { "Tak fordi du har delt } \\
\text { din historie med os. } \\
\text { Det kræver mod! Kan } \\
\text { sagtens forstå dig, da } \\
\text { jeg selv er fattig stude- } \\
\text { rende." (155) }\end{array}$ \\
\hline Itvivl/neutral & $\begin{array}{l}\text { “Du er træt af at være } \\
\text { fattig, ok. Men hvad } \\
\text { er pointen med at } \\
\text { fortælle det? Er der } \\
\text { fordi, du gerne vil have } \\
\text { hjælp til et eller andet, } \\
\text { f.eks. flere penge? } \\
\text { Eller er det bare for } \\
\text { at få medfølelse eller } \\
\text { forståelse?” (2) }\end{array}$ & $\begin{array}{l}\text { "http://www.findbolig. } \\
\text { nu/ (søg på roskilde, } \\
\text { sorter efter pris. Nu } \\
\text { koster det kun 2794, + } \\
\text { du bor tættere på RUC, } \\
\text { så kan du også droppe } \\
\text { uddannelseskortet (...) } \\
\text { Inkl. SU-lånet, så har } \\
\text { du nu ca. } 4000 \text { til rådig- } \\
\text { hed. Det er da rimelig } \\
\text { ok? Uden lån: 1500. Det } \\
\text { er da også ok?" (187) }\end{array}$ & $\begin{array}{l}\text { “Selv har jeg aldrig } \\
\text { været medlem } \\
\text { af nogen politisk } \\
\text { forening, men naar } \\
\text { jeg læser dit indlæg, } \\
\text { falder ideen først og } \\
\text { fremmest paa at det } \\
\text { skulle du gøre... Altsaa } \\
\text { melde dig ind i en } \\
\text { politisk ungdomsorga- } \\
\text { nisation” (178) }\end{array}$ \\
\hline Uenig/kritik & $\begin{array}{l}\text { “[D]it største problem } \\
\text { er 1) at din familie } \\
\text { åbenbart ikke anerken- } \\
\text { der din pengemangel } \\
\text { (...) og 2) At du lader } \\
\text { dig påvirke ALT for } \\
\text { meget af de af dine } \\
\text { studievenner, som (...) } \\
\text { [bl.a. har] studiejobs } \\
\text { (...) Det er kampe som } \\
\text { du må tage med dig } \\
\text { selv og dem." (88) }\end{array}$ & $\begin{array}{l}\text { “Jeg er studerende. } 0 \mathrm{~g} \\
\text { jeg er uenig i at det er } \\
\text { synd for studerende. } \\
\text { Mine faste udgifter } \\
\text { er også ca. } 4800 \text { (...) } \\
\text { [Jeg kan] tage SU lån } \\
\text { (...) (det billigste lån i } \\
\text { verden?), som jeg nemt } \\
\text { kan tilbagebetale når } \\
\text { jeg får et job (...) Og } \\
\text { sidst kan jeg sfl få et } \\
\text { studiejob." (6) }\end{array}$ & $\begin{array}{l}\text { "Gud hvor blev jeg } \\
\text { træt af at læse dit ind- } \\
\text { læg - og det var blot } \\
\text { en fattig sætning!" (92) }\end{array}$ \\
\hline
\end{tabular}


I de kommentarer der handlede om indlæggets primære formål, gik en række argumenter igen. Generelt bekræftede de debattører der var enige med, eller som støttede SVJ, at nogle studerende blev ekskluderet fordi de ingen penge havde, og medgav at der eksisterede mange fordomme om studerendes økonomi og forbrugsmønstre. De genkendte "frustrationen over, at skolens julefest igen skal holdes på en natklub, hvor en øl koster 45,-” (474) og mente også at samfundet anså studerende for at være nogle "latte-drikkende forkælede forbrugsdyr" (1.830). Ifølge debattørerne i denne kategori burde venner og familier blive bedre til at tage højde for studerendes økonomi ved sociale sammenkomster: "Jeg synes (...) at vi som studerende skal blive bedre til at lave ting, der ikke koster penge når vi skal være sociale”, skrev en debattør for eksempel (941).

Omvendt anfægtede nogle af de debattører der også kommenterede det primære formål, men som var uenige med eller kritiske over for SVJ, at studerende blev ekskluderet på grund af deres $ø$ konomi; det var ikke deres erfaring. "Jeg oplever netop, at jeg er "den fattige studerende", og alle omkring mig tager næsten for mange hensyn”, indvendte en debattør for eksempel (361). Generelt mente disse debattører at SVJ selv kunne løse sit problem ved at droppe forbrugsræset, tale med sine venner og familie og så i øvrigt tage initiativ til billige sammenkomster. Vel at mærke hvis ikke hendes venner og familie var helt så "monster usympatiske" (552) som de lød. Var de det, burde SVJ revurdere disse relationer: "Drop dine forkælede RUC-venner" (460) og "Få dig en ny familie” (552), lød det eksempelvis.

Blandt de kommentarer der handlede om det primære formål, var der kun meget få der gav udtryk for tvivl, eller som var neutrale. Ét eksempel er dog eksemplet i Tabel 1. Her metakommenterede en debattør det forhold at SVJ's indlæg indeholdt to budskaber, og spurgte om det var det ene eller det andet som SVJ søgte tilslutning til. Med sine relativt neutralt formulerede spørgsmål tog han imidlertid ikke eksplicit stilling til nogen af dem.

I de kommentarer der handlede om indlæggets sekundære formål, gik en række argumenter også igen. Generelt mente de debattører der var uenige med, eller som kritiserede SVJ, bl.a. at hun burde være taknemmelig for sin gratis uddannelse, sin gratis 
SU og sit billige studielån, og at hun i øvrigt burde tage ansvar og gøre noget selv såsom at få sig et job, tage et lån, flytte til noget billigere eller droppe ud. "[H]vorfor tager du ikke et studiejob så har du råd til cafe latten... Synes faktisk du burde være taknemmelig for alt det du får", skrev en debattør for eksempel (1.305). At det kunne lade sig gøre at gennemføre en uddannelse på de vilkår som SVJ studerede under, var flere af debattørerne selv eksempler på; beretninger om hvordan de selv havde klaret sig igennem, og udsagn som det følgende gik igen i disse kommentarer: "Vi HAR prøvet at leve under de forhold og ved du hvad? Vi er her stadig, vi overlevede!" (314)

Omvendt argumenterede de debattører der var enige med SVJ, eller som støttede hende, for at det slet ikke var så let at finde et studiejob og en billig bolig eller droppe licensen og månedskortet til bus og tog. Igen var egne erfaringer hyppigt brugte belæg. "Er selv på SU og kan ikke engang få den til at dække min bolig - som er valgt af nød", konstaterede en debattør som underskrev sig "En anden Sophie" (807). I øvrigt mente disse debattører at SVJ og hendes forældre selv betalte for den uddannelse og SU hun fik. "[U]dd. er bestemt ikke gratis i Danmark vi betaler ALLE dyrt for den igennem skatten" (327) og "Det er MINE forældre som har betalt for min SU via deres skat” (25), lød det eksempelvis. Endelig mente debattørerne i denne kategori at det var vigtigt at huske at ikke alle studerende havde den samme (økonomiske) støtte med hjemmefra, de samme forudsætninger for at læse og lære eller det samme overskud til både at studere og arbejde. Som en debattør formulerede det: "[S] tuderende er forskellige og har forskellige evner og ressourcer, ikke alle lige er stærke og magter det samme." (1.955)

Andre kommentarer der handlede om det sekundære formål i SVJ's debatindlæg, udtrykte tvivl eller var neutrale. Som det fremgår af eksemplet i Tabel 1, modtog SVJ adskillige økonomiske råd i kommentarsporet. Ved alene at råde hende til hvordan hun kunne justere sine udgifter og dermed hæve sit rådighedsbeløb, tog debattørerne imidlertid ikke eksplicit stilling hverken for eller imod argumentationen i indlægget. I andre kommentarer der hørte til i denne kategori, delte debattører der studerede eller havde gjort det, deres egne budgetter eller erfaringer, vel at mærke uden at eksplicitere om de var enige eller uenige, støt- 
tende eller kritiske i forhold til SVJ og hendes indlæg. Principielt kunne disse budgetter og beretninger både fungere som belæg for at man havde få penge som studerende, og at det ikke desto mindre var muligt at klare sig. Andre debattører i samme kategori stillede spørgsmål til SVJ's budget eller præciserede oplysningerne i det, men forholdt sig neutrale. For eksempel spurgte en debattør hvordan SVJ's budget ville se ud hvis hun medregnede det studielån hun tog (1.530), mens en anden præciserede at den indtægt fra SU som SVJ havde angivet i sit budget, var hvad der var tilbage efter skat (1.590). Endelig ekspliciterede nogle debattører i kategorien at de var i tvivl om hvad de skulle mene. "Jeg er noget splittet” (998) og “Er jeg den eneste, der er splittet?” (1.099), hed det eksempelvis.

Endelig gik en række træk igen i de kommentarer der handlede om noget andet end de to formål i SVJ's indlæg. Som de to eksempler i Tabel 1 illustrerer, udtrykte nogle debattører støtte eller kritik uden at eksplicitere hvilke specifikke dele af indlægget som de støttede og kritiserede. På den ene side omtalte de negative debattører SVJ's indlæg som et “tudeindlæg (...)” (261) og noget "klynkeri" (338). På den anden side kritiserede de positive debattører de mange negative kommentarer, ofte med henvisning til tonen i dem, og kom i forlængelse af dette med mere eller mindre eksplicitte støtteerklæringer til fordel for SVJ. Disse debattører mente at kommentarerne var symptom på en udbredt mangel på empati og solidaritet i dagens Danmark. Som en debattør formulerede det: “[D]enne debat (...) vil stå tilbage som en lysende skamstøtte for hvor lavt et niveau danskernes empati kunne nå.” (1.263)

Andre kommentarer der handlede om noget andet end de to formål i SVJ's indlæg, udtrykte tvivl eller var neutrale. Ud over indfald og digressioner som den strøtanke en debattør delte i eksemplet i Tabel 1, indeholdt kommentarerne i denne kategori blandt andet ukommenterede links til andre netsteder og metakommentarer der begræd tonen i kommentarsporet eller i navngivne debattørers kommentarer, vel at mærke uden at de pågældende debattører samtidig indikerede om de var enige eller uenige med SVJ. Eksempelvis konstaterede en debattør uden at uddybe sit synspunkt yderligere: "Hold op hvor er der mange bitre røvhuller, efter kommentarerne at dømme.” (872) 
Tæller man op hvordan de mange kommentarer fordelte sig på de ni kategorier jeg har karakteriseret ovenfor, tegner to pointer sig som særligt centrale for den videre analyse. For det første var der langt flere debattører der kommenterede SVJ's budskab om at hun var træt af at være fattig, end der var debattører der kommenterede hendes budskab om at hun var træt af at ingen udviste forståelse og tolerance for at det forholdt sig sådan. Hele tre ud fire $(75 \%)$ kommentarer handlede om debatindlæggets sekundære formål, mens kun omkring én ud af ti (11\%) handlede om det primære. Flertallet af debattørerne på politiken.dk var med andre ord mere optagede af SVJ's definition af fattigdom end hendes oplevelse af eksklusion.

For det andet var der samlet set flere debattører der udtrykte enighed eller støtte i forhold til SVJ og hendes indlæg, end der var debattører der udtrykte uenighed eller kritik. Det første gjaldt en lille majoritet ( $45 \%$ ), mens det sidste gjaldt en stor minoritet (38\%). Erklæringerne af enighed og uenighed hang dog sammen med om debattørerne kommenterede indlæggets primære eller sekundære formål. I de kommentarer der handlede om det primære formål, udtrykte en klar majoritet (69 \%) enighed eller støtte, mens en minoritet (24\%) udtrykte uenighed eller kritik; i dem der handlede om det sekundære formål, udtrykte en lille majoritet (44\%) uenighed eller kritik, mens en stor minoritet (40 \%) udtrykte enighed eller støtte. Som den næste analyse vil vise, står dette resultat i kontrast til den omtale debatten fik i danske medier.

\section{Fra få journalister til mange: Hvad skrev journalister om debatten?}

I analysens tredje og sidste trin analyserer jeg medieomtalen af SVJ's debatindlæg og den debat det afstedkom, baseret på et korpus af 15 tekster fra Politiken og politiken.dk og 13 tekster fra andre danske nyhedsmedier. Teksterne har jeg fundet ved at søge på kombinationer af ordene "Sofie", “Jensen", "fattig” og “SU” på Google og i Infomedia. Jeg har begrænset mine søgninger til perioden 1. januar 2012 til 1. januar 2013. 
I løbet af tre døgn opnåede SVJ's debatindlæg status af at være det mest læste og mest kommenterede nogensinde på politiken.dk. ${ }^{16}$ Da Politikens journalister i dagene umiddelbart efter fulgte op på debatten, syntes de da også imponerede over reaktionens omfang og fremhævede for eksempel at indlægget "indtil videre [havde] affødt flere end 1.000 læserkommentarer"17, og at "over 1000 læsere [havde] kommenteret [det] på politiken. dk." ${ }^{18}$ På baggrund af disse første omtaler var det imidlertid ikke helt klart hvad debatten egentlig handlede om. I en artikel på politiken.dk søndag formiddag, dagen efter at indlægget var blevet lagt på nettet, betonede en journalist at SVJ "kæmpe[de] for retten til at kalde sig for fattig", ${ }^{19}$ og fremhævede dermed det sekundære formål i debatindlægget. Omvendt betonede en journalist i en artikel i Politiken mandag morgen at SVJ mente at “[m]anglen på penge [var] direkte ekskluderende", og at "hun savne[de] forståelse fra både samfund og medstuderende." ${ }^{20}$ Han fremhævede altså det primære formål i indlægget.

De to journalister var dog enige om hvad et flertal af dem der havde skrevet kommentarer, mente: “[D]er er langt mellem dem, der udviser sympati for den fattige studerende", ${ }^{21}$ hed det i artiklen søndag, mens det i artiklen mandag lød at "selv om nogle erklære[de] sig enige (...), [tog] de fleste skarp afstand". ${ }^{22}$ Denne udlægning blev i begge tilfælde underbygget med en række eksempler: "Pinligt indlæg. Vi skal have et opgør med krævementaliteten i DK. (...)” (96), blev en bruger citeret for i artiklen om søndagen, mens en anden blev citeret for følgende opråb: “Vågn op, Danmark! Prøv dog at se, hvilke snotforkælede børn velfærdsmonstret har skabt! (...)" (119). ${ }^{23}$ Denne udlægning blev nuanceret en anelse til sidst i artiklen: "Sympatien er i undertal, men den er der", hed det under underrubrikken "En smule sympati”. ${ }^{24}$ Også nuanceringen blev underbygget med et citat: "Jeg skammer mig over de mennesker, der bare sjofler en ung studerendes nødråb. Skammer mig over, hvor vi danskere er endt: I en evindelig nedrakning af hinanden og af andres vilkår. (...)” (47). ${ }^{25}$ På trods af at denne sidste kommentar var et eksempel på at ikke alle var efter SVJ i kommentarsporet, bekræftede den ikke desto mindre den overordnede udlægning, nemlig at flertallet 'rakkede ned' på den studerende. 
De to nyhedshistorier var symptomatiske for hvordan Politikens journalister omtalte og udlagde debatten på netavisen $\mathrm{i}$ ugerne og månederne der fulgte. Her gik både den kvantitative fascination og den kvalitative forståelse der karakteriserede de første omtaler, igen.

I 11 af de 13 artikler der blev publiceret efter de to første omtaler, fremhævede avisens journalister hvor mange gange indlægget var blevet læst og kommenteret. Også her hed det at indlægget "indtil videre" ${ }^{26}$ og "foreløbig" ${ }^{27}$ havde affødt "hundrede- og atter hundredevis", 28 "over 1.000 " 29 og endda "flere end 2.000 kommentarer"30 på politiken.dk, og at det var det "mest diskuterede og mest læste debatindlæg nogensinde" ${ }^{31}$ på netavisen. I 4 af de 13 artikler lagde journalisterne desuden vægt på de specifikke læser- og besøgstal SVJ's indlæg havde resulteret i: “270.000 læsere læste hendes artikel i debatsektionen, og 100.000 (ny rekord!) klikkede ind på nettet", lød det et sted. ${ }^{32}$

I 8 ud af de 13 artikler der fulgte efter de to første omtaler, kommenterede Politikens journalister hvilke holdninger der kom til udtryk i de mange kommentarer, og i samtlige tilfælde slog journalisterne fast at flertallet af kommentarerne var negative over for SVJ og hendes indlæg. Denne udlægning blev i løbet af det næste år gentaget med forskellig ordlyd i avisens dækning af debatten: Efter nogle dages debat skrev en journalist at selvom den studerende ikke selv syntes "at hendes indlæg [var] så kontroversielt endda", mente "læserne derimod (...) at Sofie [skulle] tage sig sammen"; ${ }^{3}$ efter en uge hed det at "[d]e fleste debattører [var] uenige med Sofie[s] sag”; ;4 efter en måned at "[l]angt hovedparten af kommentarskribenterne stillede sig uforstående over for den selvudnævnte fattige studerendes problemer"; 35 efter et halvt år at “[i]ndlæg efter indlæg kaldte hende forkælet, kritiserede hende (...) og kom med meget kontante råd"; ${ }^{36}$ og endelig efter ni måneder at "langt de fleste kritiserede hende for at være forkælet og krævende". ${ }^{37}$ Det medie der havde hovedansvaret for at SVJ fik så meget opmærksomhed som hun fik, havde med andre ord også et væsentligt ansvar for at den dominerende udlægning af debatten blev at det store flertal skældte ud på hende.

I dagene efter at SVJ's indlæg var blevet publiceret på politiken. $\mathrm{dk}$, spredte debatten sig til flere andre medier, online såvel som offline. I 9 ud af de 13 tekster hvor debatten blev omtalt i andre 
medier end Politiken og politiken.dk, henviste omtalerne til det oprindelige kommentarspor på Politikens netavis. Journalister og debattører ansat på danske nyhedsmedier indledte i $7 \mathrm{ud}$ af de 13 tekster med at konstatere at SVJ's indlæg ikke blot havde fået mange, men rekordmange kommentarer på politiken.dk, og i $9 \mathrm{ud}$ af de 13 tekster hed det at flertallet af kommentarerne var kritiske. Præcis som tilfældet var i Politikens omtaler, blev det i næsten identiske vendinger fremhævet at indlægget "indtil videre" ${ }^{38}$ og "[l]ige nu" 39 havde fået "flere end $1500 " 40$ og "flere tusinde" 41 kommentarer på politiken.dk, og at det dermed var det "mest diskuterede og mest læste debatindlæg i Politiken nogensinde.” ${ }^{42}$ Også Politikens udlægning af hvad den dominerende holdning i kommentarsporet var, blev gentaget. Således hed det at SVJ havde udløst en 'orkan', ${ }^{43}$ "en lavine" 44 og en "tusindehær(...) af efterfølgende kommentarer", ${ }^{45}$ og at det var en "fortrinsvis rasende", ${ }^{46}$ 'massiv og negativ og unuanceret', ${ }^{47}$ 'overvejende negativ', ${ }^{48}$ "overvældende" og "rasende” ${ }^{49}$ samt "voldsom(...) kritik, der [var] (...) haglet ned over" ${ }^{50}$ hende. Da debatten fik omtale i tv, kunne Deadline på DR2 rapportere at SVJ's indlæg "faldt så mange for brystet, at flere end 1800 læsere indtil videre [havde] svaret", ${ }^{51}$ og det samme konkluderede finansnyhederne på TV 2: "Debatindlægget har været genstand for stor debat, og de fleste reaktioner har været kritiske." ${ }^{52}$ Hvorvidt der var tale om egne vurderinger eller blot reproduktioner af Politikens udlægning af debatten, er uvist. Men selvom det varierede hvad journalisterne og debattørerne mente om kritikken - nogle var enige i den, andre ikke - så bekræftede de i hvert fald at stemningen generelt var imod SVJ i kommentarsporet på politiken.dk.

Hvad debattørerne på Politikens netavis reagerede så stærkt på, var ikke altid lige klart i den megen medieomtale. Men at dømme efter hvordan journalisterne lagde op til debat mellem brugerne på deres netsteder eller gæster de havde inviteret i studiet, syntes de at mene at det var spørgsmålet om hvorvidt SVJ var fattig eller ej, altså debatindlæggets sekundære formål, som fortrinsvis skabte så meget debat og vrede. To af landets største netaviser, ekstrabladet.dk og bt.dk, spurgte deres brugere: "22årig RUC-studerende vil også kaldes fattig, selvom hun får SU. Hvad synes du?" 53 og "Hvad mener du? Har Sofie V. Jensen ret i, at hun er fattig?" ${ }^{4}$. Deadline bad et panel debattere indlægget 
under overskriften "Fattig eller bare klynk?", ${ }^{55}$ mens TV 2 | Finans spurgte brugerne på finans.tv2.dk: "Klynker Sofie V. Jensen eller har hun ret i, at de studerende lever et hårdt og fattigt liv?" ${ }^{56}$ Endelig lagde Pressen på P3 op til debat på dr.dk efter at SVJ havde været i studiet, med spørgsmålet: "Er det okay for Sofie at kalde sig fattig?" ${ }^{7}$ På tværs af netaviser, tv og radio lagde journalisterne altså vægt på at debatten handlede om definition - hvorvidt SVJ var fattig - og ikke eksklusion.

\section{Diskussion}

Umiddelbart var det forløb som SVJ's debatindlæg igangsatte, et eksempel på hvordan netaviser kan understøtte "debat fra neden", altså debat der har sit arnested i bunden af samfundets kommunikative hierarki: Med politiken.dk som det primære springbræt fik en hidtil ukendt studerende sat sin egen og andre studerendes økonomi på den offentlige dagsorden, ikke kun på tværs af nyhedssites, blogs og debatfora på nettet, men også via traditionelle massemedier som aviser, tv og radio. Og fordi den megen medieomtale lige så meget gik på de mange kommentarer til debatindlægget som på selve indlægget, fik debatten blandt de borgere der tog del i debatten på Politikens netavis, ligeledes stor og bred medieopmærksomhed.

Som sådan kunne forløbet synes at bekræfte hypotesen om at digitale netværksmedier som netaviser er med til at demokratisere den offentlige meningsdannelse ved at muliggøre en mere direkte kommunikation mellem borgere og magthavere og dermed overflødiggøre journalister som kommunikationens moderatorer. En sådan hypotese kan mine analyser dog ikke bekræfte. Tværtimod illustrerer de hvordan journalisters traditionelle privilegerede position som fortolkere og formidlere af debat blandt borgere ikke blot fastholdes, men forstærkes på nettet. Det var journalisters stærkt forenklede udlægning af hvad debatten blandt borgerne på politiken.dk handlede om, og hvad de i øvrigt mente, der vandt hævd i den medierede offentlighed som manifesterer sig i denne artikels analysemateriale (jævnfør Hauser, 1999: 64 og 97). 
De indledende omtaler af SVJ's indlæg og den debat det afstedkom på politiken.dk, bar som sagt præg af den flertydighed som også var at finde i indlægget, med hensyn til hvad den studerendes budskab egentlig var. Politikens journalister var - uden at de selv kommenterede det - uenige om hvorvidt indlægget og den debat det skabte, handlede om at SVJ var træt af at være fattig (indlæggets sekundære formål), eller at hun savnede forståelse og tolerance for at det forholdt sig sådan (dets primære formål). Efterhånden som omtalen af indlægget og debatten spredte sig til andre medier, og omtaler avlede flere omtaler, blev det dog det sekundære formål der løb med overskrifterne. Udlægningen af hvad debatten handlede om, gik med andre ord fra at være flertydig til at blive mere og mere entydig: Det grundlæggende spørgsmål blev om SVJ var “[f] attig eller forkælet”. ${ }^{58}$

Hvor der skete en udvikling i journalisters udlægning af hvad debatten handlede om, var de til gengæld sikre i deres udlægning af hvad de mange borgere der tog del i den, mente. Som sagt viser min analyse at der var et lille flertal af debattørerne på politiken.dk der var positivt over for SVJ og hendes indlæg, mens et stort mindretal var negativt. Den dominerende historie i danske medier var imidlertid en anden, nemlig at det store flertal af dem der skrev kommentarer på Politikens netavis, var uenige, kritiske og i flere tilfælde decideret fjendtlige. I medieomtalen blev den offentlige opinion i kommentarsporet på politiken.dk altså ikke blot unuanceret formidlet som mere entydig end tilfældet var, men decideret misvisende udlagt som overvejende negativ og kritisk over for den borger der tog initiativ til debatten, og de synspunkter hun gav udtryk for.

Efterhånden som forløbet skred frem, blev de ni kategorier af kommentarer som jeg har påvist i min analyse, altså reduceret til én: Debatten handlede om hvorvidt SVJ var fattig eller ej, og det mente debattørerne på politiken.dk $i k k e$ at hun var. Det flerstemmige kor af argumenter som en retorisk nærlæsning afdækker, blev i medieomtalen fremstillet som et enstemmigt brøl - for nu at vende journalisternes hyperbolske sprogbrug mod dem selv.

Den skråsikre udlægning var påfaldende taget i betragtning hvor mange kommentarer journalisterne opsummerede. Sådan som kommentarsporet på politiken.dk var indrettet, skulle man klikke sig igennem 100 sider med kommentarer for at læse de 
kommentarer som SVJ's indlæg afstedkom bare inden for det første døgn. Som journalisternes egen fascination af reaktionens numeriske omfang afspejlede, var den overvældende grænsende til uoverskuelig. På den baggrund kunne man tro at journalisterne ville være mere tilbageholdende med at udlægge den offentlige opinion der manifesterede sig i kommentarerne, så entydigt. Som jeg var inde på i artiklens indledning, viser flere studier nemlig at journalister der arbejder med debat blandt borgere på netaviser, er særdeles bevidste om hvor vanskeligt det kan være at moderere og samle op på hvad borgerne skriver, ikke mindst fordi borgerne til tider skriver så mange kommentarer at deres meninger drukner i mængden.

Som min case illustrerer, kan kommentarer på netaviser dog undertiden få betydning for den offentlige meningsdannelse alene i kraft af deres mængde. For selvom den offentlige opinion i de mange kommentarer på politiken.dk blev misvisende udlagt i danske medier, så var kommentarerne takket være deres antal ikke desto mindre med til at skabe opmærksomhed omkring SVJ og hendes debatindlæg, ikke kun i de dage hvor debatten var på sit højeste, men også i månederne der fulgte. I sommerferien fik SVJ igen taletid i Politiken i et stort interview i serien "Hvad blev der af...?"; 59 omkring studiestart fik hun oprejsning på avisens forside da en forbrugerøkonom gav hende ret i at studerende var fattige; ${ }^{60}$ og ved årets afslutning blev hun af avisens debatredaktører fremhævet som en der "satte dagsordenen i det forgangne år". ${ }^{11}$ Hver gang blev det fremhævet hvor mange kommentarer hendes indlæg havde fået på Politikens netavis tilbage i januar. Over tid blev de mange kommentarer med andre ord en talerstol hvorfra SVJ kunne gentage sine synspunkter. Og som min analyse har vist, deltes hendes synspunkter faktisk af flertallet af dem der kommenterede hendes indlæg.

\section{Konklusion}

Fordi digitale netværksmedier muliggør mange til mangekommunikation på en hidtil uset skala (Jensen, 2012: 187-188, 2013: 25), er ikke kun det potentielle antal af modtagere, men også afsendere større på nettet. Jo flere der ytrer sig, des færre 
bliver imidlertid hørt, også på netaviser (Hindman, 2009: 142; Winsvold, 2009: 52). I stedet koncentrerer opmærksomheden sig om de kommunikatører der nyder den i forvejen, ikke mindst journalister (Hindman, 2009: 116-117 og 122). Denne artikels casestudie illustrerer hvordan journalister ikke kun nyder særlige retoriske privilegier når de selv ytrer sig på nettet, men også når de fortolker og formidler andres ytringer samme sted. Konfronteret med det kvantitative omfang af debatter blandt borgere på nettet kommer offentlighedens forståelse af debatternes kvalitative betydning undertiden til at bero på journalisters fortolkning og formidling. Kommentarsporenes uoverskuelige karakter reaktualiserer og revitaliserer med andre ord journalisters ret til at udlægge den offentlige opinion i dem.

En central udfordring for journalistikken som såvel uddannelse som profession er derfor at styrke journalisters evne til at "læse" hvad offentligheder på nettet mener (jævnfør Hauser, 1999: 92-93). Dette er, som Gerard A. Hauser påpeger, en retorisk kompetence der kræver indsigt og færdigheder i praktisk argumentation (Hauser, 1999: 33 og 93-94). At kunne fremsætte egne argumenter og fortolke andres argumenter er to tæt forbundne aktiviteter (Hauser, 1999: 92), så bliver man bedre til det ene, bliver man også bedre til det andet. Mere grundlæggende plæderer Hauser for at fortolkere af den offentlige opinion bør forstå offentlig meningsdannelse som polyfonisk, ja, ligefrem kakofonisk (Hauser, 1999: 67, 92, 97, 100-101). Den offentlige opinion er derfor sjældent så entydig og endegyldig som eksempelvis meningsmålinger og den udbredte brug af dem i nyhedsmedierne kan give indtryk af; tværtimod er den offentlige opinion ifølge Hauser ofte flertydig og foranderlig (Hauser, 1999: 67, 91-92, 278-279). En sådan forståelse af den offentlige opinion kan være svær at forene med journalisters brug af konflikt som nyhedskriterium; som kritikere har påpeget, fører misbrug af dette kriterium indimellem til at modsætninger i samfundet forenkles, forstærkes og endda forfalskes (Kabel, 2014: 427). Skal journalister klædes på til rollen som fortolkere og formidlere af den offentlige opinion på nettet, kræver det derfor også at journalister på både uddannelser og redaktioner kritisk reflekterer over deres forståelse af hvad en offentlig opinion egentlig er, og hvilke forventninger den bør "læses” med. Styrkes journalisters 
retoriske agency i denne forstand, styrkes samtidig deres mulighed for at tilskrive en sådan handlekraft til de borgere der tager del i den offentlige meningsdannelse online.

\section{Noter}

1 Joshua Gunn og Dana L. Cloud har argumenteret for at der efter to årtiers diskussion blandt retorikere eksisterer i hvert fald tre udlægninger af retorisk agency og det forhold mellem subjekt og struktur som begrebet refererer til: en kritisk posthumanistisk der vægter strukturen, en konservativ humanistisk der vægter subjektet, og endelig en pragmatisk dialektisk der lægger vægt på det gensidige betingelsesforhold mellem de to (Gunn og Cloud, 2010: 52-57). Når jeg i denne artikel følger Gunn og Clouds anbefaling og trækker på den dialektiske mellemposition (Gunn og Cloud, 2010: 71), lægger jeg mig i forlængelse af en række nyere danske retoriske kritikker der alle har agency som det begrebsmæssige omdrejningspunkt, og som eksplicit eller implicit trækker på netop denne udlægning af begrebets betydning (Berg og Juul Christiansen, 2010: 10-11; Hoff-Clausen, 2013: 429; Isager, 2009: 271-272; Villadsen, 2008: 27).

2 Sofie V. Jensen, "Myten om det fede studieliv er falsk", Politiken, 7. januar 2012, 8

3 Sofie V. Jensen, "Jeg er træt af at have en dårlig dag hver dag", 7. januar 2012, besøgt d. 19. januar 2012, http://politiken.dk/debat/ ECE1501598/jeg-er-traet-af-at-have-en-daarlig-dag-hver-dag/

4 Annelise Eskesen, "Studerende sætter rekorddebat i gang", Politiken, 12. januar 2012, 2

5 Ekstra Bladet, "Du er ikke fattig, Sofie", Ekstra Bladet, 10. januar 2012, 1

${ }^{6}$ Ida Skytte og Ulla Poulsen, "De værdigt trængende er kommet i høj kurs”, Kristeligt Dagblad, 14. januar 2012, 1

7 Morten Bruno Engelschmidt, "Klynker de fattige studerende?", 9. januar 2012, besøgt d. 31. januar 2013, http://finans.tv2.dk/nyheder/ article.php/id-47317257:klynker-de-fattige-studerende.html

8 Deadline, "11/01: Fattig eller bare klynk?", 11. januar 2012, besøgt d. 31. januar 2013, http://www.dr.dk/DR2/deadline2230/2012/01/08/151901_1_1_1.htm

9 Ekstra Bladet, "Du er ikke fattig..."

${ }^{10}$ Jakob Sorgenfri Kjær, "Studerende lever i fattigdom”, Politiken, 3. september 2012, 1 
11 Per Michael Jespersen, “Domineres medierne af røv og nøgler?”, 28. januar 2012, besøgt d. 31. januar 2013, http://politiken.dk/debat/ profiler/permichael/ECE1521869/domineres-medierne-af-roev-ognoegler/

12 Kristian Madsen, “Fattig? Næh, da jeg var ung, du...", Politiken, 14. januar 2012, 7

13 Allan Larsen, "Fattig-Carina fik danskerne op af stolen", 18. december 2012, besøgt d. 23. maj 2014, http://www.ugebreveta4.dk/fattigcarina-fik-danskerne-op-af-stolen_14183.aspx

14 Anne Sofie H. Schrøder, "Fattigdomsdiskussion raser hos kontanthjælpsmodtager”, 28. november 2011, besøgt d. 23. maj 2014, http:// www.b.dk/politiko/fattigdomsdiskussion-raser-hos-kontanthjaelpsmodtager

${ }_{15}$ Min analyse af kommentarerne til SVJ’s debatindlæg på politiken.dk baserer sig på en udgave af kommentarsporet der stammer fra d. 19. januar 2012, og som jeg har arkiveret som pdf-filer. Da debatten var stilnet af på dette tidspunkt, er der grund til at tro at der er tale om det komplette korpus af kommentarer som indlægget afstedkom på Politikens netavis i vinteren 2012.

${ }^{16}$ Eskesen, "Studerende sætter..."

17 Katrine Jo Andersen, "Der er ikke meget sympati for den fattige studerende”, 8. januar 2012, besøgt d. 31. januar 2013, http://politiken. dk/debat/ECE1501942/der-er-ikke-meget-sympati-for-den-fattigestuderende/

18 Peter N. Christensen, "Ringe sympati for fattig studerende", Politiken, 9. januar 2012, 2

${ }^{19}$ Andersen, "Der er ikke meget..."

${ }^{20}$ Christensen, "Ringe sympati..."

${ }^{21}$ Andersen, "Der er ikke meget..."

22 Christensen, "Ringe sympati..."

${ }^{23}$ Andersen, "Der er ikke meget..."

${ }^{24}$ Andersen, "Der er ikke meget..."

${ }^{25}$ Andersen, "Der er ikke meget..."

${ }^{26}$ Andersen, "Der er ikke meget..."

${ }^{27}$ Mette Højbjerg, "Fattig eller forkælet”, Politiken, 14. januar, 2012, 8

28 Annelise Hartmann Eskesen, "Studerende efter vild fattig-debat: Måske skal man bare lade tabu være tabu”, 11. januar 2012, besøgt d. 31. januar 2013, http://politiken.dk/debat/ECE1504039/studerendeefter-vild-fattig-debat-maaske-skal-man-bare-lade-tabu-vaere- 
tabu/

${ }^{29}$ Christensen, "Ringe sympati..."

${ }^{30}$ Politiken, "Tyskere undrer sig over dansk studerendes "luksusproblemer”," 3. februar 2012, besøgt d. 31. januar 2013, http://politiken.dk/ debat/ECE1528508/tyskere-undrer-sig-over-dansk-studerendes-luksusproblemer/

${ }^{31}$ Eskesen, "Studerende efter vild..."

32 Per Michael Jespersen, “Kære læsere, vi siger nitten tusinde tak”, Politiken, 29. december 2012, 7

33 Eskesen, "Studerende efter vild..."

${ }^{34}$ Højbjerg, "Fattig eller forkælet"

${ }^{35}$ Politiken, "Tyskere undrer sig..."

${ }^{36}$ Jacob Fuglsang, “Da Sofie fik fattigrøven på komedie”, Politiken, 1. juli 2012, 6

${ }^{37}$ Kjær, "Studerende lever i..."

${ }^{38}$ Deadline, "11/01: Fattig eller..."

39 Anne Sophia Hermansen, “Sofie-orkanen - succes som fiasko”, 12. januar 2012, besøgt d. 31. januar 2013, http://annesophia.blogs.berlingske.dk/2012/01/12/sofie-orkanen-succes-som-fiasko/

${ }^{40}$ Tom Jensen, “Sofies verden”, 9. januar 2012, besøgt d. 31. januar 2013, http://tomjensen.blogs.berlingske.dk/2012/01/09/sofies-verden/

${ }^{41}$ Hermansen, "Sofie-orkanen..."

${ }^{42}$ Deadline, "11/01: Fattig eller..."

${ }^{43}$ Hermansen, "Sofie-orkanen..."

44 Morten Mærsk, “Fattig-studerende: Jeg kræver ikke flere penge”, 9. januar 2012, besøgt d. 31. januar 2013, http://www.bt.dk/danmark/ fattig-studerende-jeg-kraever-ikke-flere-penge

${ }^{45}$ Sofie Rye, "Er fattigdom noget, der kun findes i Afrika", metroXpress Aarhus/Vest, 10. januar 2012, 13

${ }^{46}$ Jensen, "Sofies verden"

${ }^{47}$ Rye, "Er fattigdom noget..."

${ }^{48}$ Hermansen, "Sofie-orkanen..."

${ }^{49}$ Sebastian Gjerding, “De provokerende fattige”, Information, 14. januar 2012, 14

50 Camilla Paaske Hjort, "Hadet til de produktive klasser", 16. januar 2012, besøgt d. 31. januar 2013, http://www.b.dk/kronikker/hadettil-de-produktive-klasser

${ }^{51}$ Deadline, "11/01: Fattig eller..."

${ }^{52}$ Engelschmidt, "Klynker de fattige...” 
53 Anders Kjærulff, "Studerende: Jeg vil også kaldes fattig”, 9. januar 2012, besøgt d. 31. januar 2013, http://ekstrabladet.dk/nationen/ article1687880.ece

${ }^{54}$ Morten Mærsk, “Studerende: Forstå nu, jeg er fattig!”, 9. januar 2012, besøgt d. 31. januar 2013, http://www.bt.dk/danmark/studerendeforstaa-nu-jeg-er-fattig

${ }^{55}$ Deadline, "11/01: Fattig eller..."

${ }^{56}$ Engelschmidt, "Klynker de fattige..."

${ }^{57}$ Jonas Delfs, “Er studerende fattige?", 9. januar 2012, besøgt d. 31. januar 2013, http://www.dr.dk/p3/programmer/pressen/2012/01/09/erstuderende-fattige

${ }^{58}$ Højbjerg, "Fattig eller forkælet"

${ }^{59}$ Fuglsang, "Da Sofie fik..."

${ }^{60}$ Kjær, "Studerende lever i..."

${ }_{61}$ Mads Zacho Teglskov og Per Michael Jespersen, "Vi diskuterede voldsofre, fattige studerende og sexovergreb i 2012”, 3. januar 2013, besøgt d. 31. januar 2013, http://politiken.dk/debat/ECE1854738/vidiskuterede-voldsofre-fattige-studerende-og-sexovergreb-i-2012/

\section{REFERENCER}

Albeck, Ulla (2000). Dansk Stilistik, 7. udgave, København: Gyldendal.

Berg, Kristine Marie og Tanja Juul Christiansen (2010). "Retorisk eksklusion: Festen i Hyskenstræde som retorisk handling”, Rhetorica Scandinavica, nr. 54, pp. 7-28.

Bergström, Annika og Ingela Wadbring (2015). "Beneficial yet crappy: Journalists and audiences on obstacles and opportunities in reader comments", European Journal of Communication, 30. årgang, nr. 2, pp. 137-151.

Bitzer, Lloyd F. (1968). “The Rhetorical Situation”, Philosophy \& Rhetoric, 1. årgang, nr. 1, pp. 1-14.

Braun, Joshua og Tarleton Gillespie (2011). "Hosting the Public Discourse, Hosting the Public: When Online News and Social Media Converge”, Journalism Practice, 5. årgang, nr. 4, pp. 383-398.

Bro, Peter (2009). "Nyhedsmediernes funktioner”, pp. 382-385 i Søren Kolstrup, Gunhild Agger, Per Jauert og Kim Schrøder (red.), Medie- og kommunikationsleksikon, 1. udgave, Frederiksberg: Samfundslitteratur.

Bro, Peter og Filip Wallberg (2015). "Gatekeeping in a Digital Era: Principles, Practices and Technological Platforms”, Journalism Practice, 9. 
årgang, nr. 1, pp. 92-105.

Canter, Lily (2013). “The Misconception of Online Comment Threads: Content and Control on Local NewspaperWebsites", Journalism Practice, 7. årgang, nr. 5, pp. 604-619.

Ceccarelli, Leah (2001). "The Close Textual-Intertextual Analysis: Combining Rhetorical Criticism and Historical Research", pp. 6-9 i Leah Ceccarelli, Shaping Science with Rhetoric: The Cases of Dobzhansky, Schrodinger, and Wilson, Chicago, IL: The University of Chicago Press. Chung, Deborah Soun (2007). "Profits and Perils: Online News Producers' Perceptions of Interactivity and Uses of Interactive Features", Convergence: The International Journal of Research into New Media Technologies, 13. årgang, nr. 1, pp. 43-61.

Diakopoulos, Nicholas og Mor Naaman (2011). “Towards quality discourse in online news comments", pp. 133-142 i Proceedings of the ACM 2011 conference on Computer supported cooperative work, New York, NY: Association for Computing Machinery.

Domingo, David (2008). "Interactivity in the Daily Routines of Online Newsrooms: Dealing with an Uncomfortable Myth", Journal of Computer-Mediated Communication, 13. årgang, nr. 3, pp. 680-704.

Graham, Todd og Scott Wright (2015). "A Tale of Two Stories from 'Below the Line': Comment Fields at the Guardian”, The International Journal of Press/Politics, 20. årgang, nr. 3, pp. 317-338.

Gunn, Joshua og Dana L. Cloud (2010). "Agentic Orientation as Magical Voluntarism”, Communication Theory, 20. årgang, nr. 1, pp. 50-78.

Habermas, Jürgen (2006). "Political Communication in Media Society: Does Democracy Still Enjoy an Epistemic Dimension? The Impact of Normative Theory on Empirical Research", Communication Theory, 16. årgang, nr. 4, pp. 411-426.

Hansen, Ejvind (2015). “Journalistik som en hermeneutisk og dekonstruktiv intervention i den distribuerede offentlighed", Journalistica, nr. 1, pp. 96-115.

Hauser, Gerard A. (1999). Vernacular Voices: The Rhetoric of Publics and Public Spheres, Columbia, SC: University of South Carolina Press.

Hauser, Gerard A. (2007). "Vernacular Discourse and the Epistemic Dimension of Public Opinion”, Communication Theory, 17. årgang, nr. 4, pp. 333-339.

Hermida, Alfred og Neil Thurman (2008). "A Clash of Cultures: The Integration of User-Generated Content within Professional Journalistic Frameworks at British Newspaper Websites", Journalism Practice, 2. 
årgang, nr. 3, pp. 343-356.

Hindman, Matthew S. (2009). The Myth of Digital Democracy, Princeton, NJ: Princeton University Press.

Hoff-Clausen, Elisabeth (2013). "Attributing Rhetorical Agency in a Crisis of Trust: Danske Bank's Act of Public Listening after the Credit Collapse”, Rhetoric Society Quarterly, 43. årgang, nr. 5, pp. 425-448.

Hoff-Clausen, Elisabeth, Christine Isager og Lisa Storm Villadsen (2005).

“Retorisk agency - Hvad skaber retorikken?", Rhetorica Scandinavica, nr. 33, pp. 56-65.

Howard, Robert Glenn (2010). "The Vernacular Mode: Locating the Noninstitutional in the Practice of Citizenship”, pp. 240-261 i Daniel C. Brouwer og Robert Asen (red.), Public Modalities: Rhetoric, Culture, Media, and the Shape of Public Life, Tuscaloosa, AL: University of Alabama Press.

Ingraham, Chris (2013). “Talking (About) the Elite and Mass: Vernacular Rhetoric and Discursive Status”, Philosophy \& Rhetoric, 46. årgang, nr. 1, pp. 1-21.

Isager, Christine (2009). "Retorisk handlekraft: Hvem giver journalisterne ordet?”, pp. 269-289 i Marie Lund Klujeff og Hanne Roer (red.), Retorikkens aktualitet: Grundbog i retorisk kritik, 2. udgave, København: Hans Reitzel.

Isager, Christine (2015). "Haderen, elskeren og læseren: Holdning, underholdning og pædagogisk potentiale i essayistisk skrivelitteratur”, Journalistica, nr. 1, pp. 4-23.

Jensen, Klaus Bruhn (2009). “Three-step flow”, Journalism, 10. årgang, nr. 3, pp. 335-337.

Jensen, Klaus Bruhn (2010). Media Convergence: The Three Degrees of Network, Mass, and Interpersonal Communication, New York, NY: Routledge.

Jensen, Klaus Bruhn (red.) (2012). A Handbook of Media and Communication Research: Qualitative and Quantitative Methodologies, 2. udgave, Abingdon, Oxon: Routledge.

Jensen, Klaus Bruhn (2013). Medier og samfund, 2. udgave, Frederiksberg: Samfundslitteratur.

Jensen, Klaus Bruhn og Rasmus Helles (2011). “The internet as a cultural forum: Implications for research”, New Media \& Society, 13. årgang, nr. 4, pp. 517-533.

Kabel, Lars (2014). “Nyhedskriterier”, pp. 425-428 i Søren Kolstrup, Gunhild Agger, Per Jauert og Kim Schrøder (red.), Medie- og kommunika- 
tionsleksikon, 3. udgave, Frederiksberg: Samfundslitteratur.

Loke, Jaime (2012). “Old Turf, New Neighbors: Journalists' Perspectives on Their New Shared Space”, Journalism Practice, 6. årgang, nr. 2, pp. 233-249.

Lund, Marie og Hanne Roer (2014). "Retorisk kritik- en oversigt”, pp. 9-36 i Marie Lund og Hanne Roer (red.), Retorikkens aktualitet: Grundbog $i$ retorisk kritik, 3. udgave, København: Hans Reitzels Forlag.

Pontoppidan, Christina (2013). Gør teksten klar: Principper for klart skriftsprog, Frederiksberg: Samfundslitteratur.

Robinson, Sue (2010). “Traditionalists vs. Convergers: Textual Privilege, Boundary Work, and the Journalist-Audience Relationship in the Commenting Policies of Online News Sites", Convergence: The International Journal of Research into New Media Technologies, 16. årgang, nr. 1, pp. 125-143.

Rønlev, Rasmus (2014). Danske netaviser som webmedier for retorisk medborgerskab, Københavns Universitet.

Singer, Jane B. (2010). "Quality Control: Perceived Effects of User-Generated Content on Newsroom Norms, Values and Routines", Journalism Practice, 4. årgang, nr. 2, pp. 127-142.

Singer, Jane B. og Ian Ashman (2009). “'Comment Is Free, but Facts Are Sacred': User-Generated Content and Ethical Constructs at the Guardian”, Journal of Mass Media Ethics, 24. årgang, nr. 1, pp. 3-21.

Thurman, Neil (2008). "Forums for citizen journalists? Adoption of user generated content initiatives by online news media”, New Media \& Society, 10. årgang, nr. 1, pp. 139-157.

Villadsen, Lisa Storm (2008). "Speaking on Behalf of Others: Rhetorical Agency and Epideictic Functions in Official Apologies”, Rhetoric Society Quarterly, 38. årgang, nr. 1, pp. 25-45.

Villadsen, Lisa Storm (2009). "Retorisk kritik”, pp. 195-218 i Charlotte Jørgensen og Lisa Storm Villadsen (red.), Retorik. Teori og praksis, Frederiksberg: Samfundslitteratur.

Winsvold, Marte (2009). "Arguing into the Digital Void?", Javnost - The Public, 16. årgang, nr. 3, pp. 39-54.

\section{FORFATTER}

Rasmus Rønlev

Adjunkt, Center for Journalistik, Syddansk Universitet roenlev@journalism.sdu.dk 